\title{
Phase transition and near-zero thermal expansion in $\mathrm{ZrFeMo}_{2} \mathrm{VO}_{12}$
}

Dongxia Chen ${ }^{\mathrm{a}}$, Baohe Yuan ${ }^{\mathrm{a}, \mathrm{b}}$, Yongguang Cheng ${ }^{\mathrm{a}}$, Xianghong Ge ${ }^{\mathrm{a}}$, Yu Jia ${ }^{\mathrm{a}}$, Erjun Liang ${ }^{\mathrm{a}, *}$, Mingju Chao ${ }^{\mathrm{a}}$

${ }^{a}$ School of Physical Science \& Engineering and Key Laboratory of Materials Physics of Ministry of Education of China, Zhengzhou University, Zhengzhou 450052, China

${ }^{\mathrm{b}}$ North China University of Water Resources and Electric Power, 450011, China

\begin{abstract}
$\mathrm{ZrFeMo}_{2} \mathrm{VO}_{12}$ material was successfully synthesized by solid-state method. The structure, phase transformation and thermal expansion of such material were studied by X-Ray powder diffraction (XRD), Raman spectra and thermal dilatometry. It crystallizes in monoclinic structure at room temperature (RT). The monoclinic structure transforms to orthorhombic structure on temperature at between 298 and $312 \mathrm{~K}$. The coefficient of thermal expansion (CTE) was measured by dilatometer to be $(0.36 \pm 0.02) \times 10^{-6} \mathrm{~K}^{-1}(401 \sim 573 \mathrm{~K})$ and calculated by XRD data to be $(0.68 \pm 0.17) \times 10^{-6} \mathrm{~K}^{-1}(423 \sim 573 \mathrm{~K})$. Both the values of intrinsic (XRD) and extrinsic (dilatometric) thermal expansion are near zero.
\end{abstract}

Keywords: Negative thermal expansion; Near-zero thermal expansion; Phase transition; Raman

\footnotetext{
* Corresponding author. Tel.: +86 371 67767838; fax: +86 37167766629.

E-mail address: ejliang@zzu.edu.cn.
} 


\section{Introduction}

Near-zero thermal expansion materials are particularly needed in the fields such as precision optics, optoelectronics and nanometer materials. It is because that most materials expand on heating that may induce thermal stresses and result in failure of devices. To solve this problem, extensive researches have been carried out on negative thermal expansion (NTE) materials, for which can be combined with positive thermal expansion materials or tailored chemically to attain near zero thermal expansion materials. Series of NTE materials have been found such as $\mathrm{AM}_{2} \mathrm{O}_{7}$ $(\mathrm{A}=\mathrm{Zr}, \mathrm{Hf} ; \mathrm{M}=\mathrm{V}, \mathrm{P})$ [1-3], $\mathrm{AM}_{2} \mathrm{O}_{8}(\mathrm{~A}=\mathrm{Zr}, \mathrm{Hf} ; \mathrm{M}=\mathrm{W}, \mathrm{Mo})$ [4-8] and $\mathrm{A}_{2} \mathrm{M}_{3} \mathrm{O}_{12}(\mathrm{~A}=$ transition metal or rare earth; $\mathrm{M}=\mathrm{W}$, Mo) $[9,10]$. Among the materials with flexible framework structure, $\mathrm{A}_{2} \mathrm{M}_{3} \mathrm{O}_{12}$ family materials can exhibit stable NTE over a wide temperature range. Furthermore, the thermal expansion coefficient (TEC) of $\mathrm{A}_{2} \mathrm{M}_{3} \mathrm{O}_{12}$ can be adjusted by varying the type and content of the substitution of cation, which provides a possible way to prepare materials with adjustable TEC, especially those with zero TEC [11]. Related reports include $\left(\mathrm{Al}_{2 x}(\mathrm{HfMg})_{1-x}\right)\left(\mathrm{WO}_{4}\right)_{3}$ [12], $\mathrm{In}(\mathrm{HfMg})_{0.5} \mathrm{Mo}_{3} \mathrm{O}_{12}$ [13], $\mathrm{Sc}_{2-x} \mathrm{Fe}_{x} \mathrm{Mo}_{3} \mathrm{O}_{12}$ [14], $\mathrm{Fe}_{2-x} \mathrm{Y}_{x} \mathrm{Mo}_{3} \mathrm{O}_{12}$ [15], $\mathrm{Fe}_{2-\mathrm{x}}(\mathrm{ZrMg})_{0.5 \mathrm{x}} \mathrm{Mo}_{3} \mathrm{O}_{12}[16]$, etc.

Many members of $\mathrm{A}_{2} \mathrm{M}_{3} \mathrm{O}_{12}$ family undergo a phase transition from monoclinic to orthorhombic phase upon heating. The phase transition temperatures for $\mathrm{Al}_{2} \mathrm{~W}_{3} \mathrm{O}_{12}, \mathrm{Al}_{2} \mathrm{Mo}_{3} \mathrm{O}_{12}$, $\mathrm{Cr}_{2} \mathrm{Mo}_{3} \mathrm{O}_{12}, \mathrm{Fe}_{2} \mathrm{Mo}_{3} \mathrm{O}_{12}, \mathrm{In}_{2} \mathrm{Mo}_{3} \mathrm{O}_{12}, \mathrm{Sc}_{2}\left(\mathrm{MoO}_{4}\right)_{3}$ have been observed and reported by Sleight and Brixner [17] to be $267 \mathrm{~K}, 473 \mathrm{~K}, 658 \mathrm{~K}, 772 \mathrm{~K}, 628 \mathrm{~K}$ and $282 \mathrm{~K}$, respectively. For near-zero thermal expansion materials associated with them, the phase transition temperature of $\operatorname{In}(\mathrm{HfMg})_{0.5} \mathrm{Mo}_{3} \mathrm{O}_{12}, \mathrm{Sc}_{2-x} \mathrm{Fe}_{x} \mathrm{Mo}_{3} \mathrm{O}_{12}(\mathrm{x}=0.7), \mathrm{Fe}_{2-x} \mathrm{Y}_{x} \mathrm{Mo}_{3} \mathrm{O}_{12}(\mathrm{x}=0.5), \mathrm{Fe}_{2-\mathrm{x}}(\mathrm{ZrMg})_{0.5 \mathrm{x}} \mathrm{Mo}_{3} \mathrm{O}_{12}$ $(\mathrm{x}=1.7)$ were reported to be $425 \mathrm{~K}, 385 \mathrm{~K}$, below $103 \mathrm{~K}$, below103 K, respectively [13-16]. Normally orthorhombic structure with corner-sharing $\mathrm{AO}_{6}$ octahedra and $\mathrm{MO}_{4}$ tetrahedra can 
accommodate for transverse thermal vibrations which are responsible for NTE [18]. The magnitude of the NTE in $\mathrm{A}_{2} \mathrm{M}_{3} \mathrm{O}_{12}$ family is related to the size of cation according to Forster et al. [19] Apart from $\mathrm{A}^{3+}$ cationic size, there may exist other factors that can influence the thermal expansion properties of some systems. It is suggested that the strength of $\mathrm{A}^{3+}-\mathrm{O}$ bond in $\mathrm{A}_{2} \mathrm{M}_{3} \mathrm{O}_{12}$ also plays a role in NTE behavior of the materials [20]. Additionally, Sleight et al. [17] investigated the relation between the phase transition temperature and $\mathrm{A}^{3+}$ cation in $\mathrm{A}_{2} \mathrm{M}_{3} \mathrm{O}_{12}$ and found that the phase transition temperature doesn't depend on the size of $\mathrm{A}^{3+}$ cation but increases with the electronegativity $(\mathrm{EN})$ of $\mathrm{A}^{3+}$ cation increasing. In practice, high phase transition temperature hinders the extensive application of the materials. Thus lowering the phase transition temperature to far below RT combined with tailoring the CTE is particularly important.

In order to lower the transition temperature of $\mathrm{Fe}_{2} \mathrm{Mo}_{3} \mathrm{O}_{12}$, some researches considered partial substitution of $\mathrm{Fe}^{3+}$ by other cations. Our previous study on substitution of $\mathrm{Y}^{3+}$ for $\mathrm{Fe}^{3+}$ found that the phase transition temperature can be effectively reduced (minimum below $103 \mathrm{~K}$ ) with increasing the contents of $\mathrm{Y}^{3+}$ in $\mathrm{Fe}_{2-x} \mathrm{Y}_{x} \mathrm{Mo}_{3} \mathrm{O}_{12}$ series materials [15]. However, these materials are highly hygroscopic due to large cation radius of $\mathrm{Y}^{3+}$ and show NTE after complete release of crystal water. By substitutional co-incorporation of $\mathrm{Zr}^{4+}$ and $\mathrm{Mg}^{2+}$, the phase transition temperatures of $\mathrm{Fe}_{2-\mathrm{x}}(\mathrm{ZrMg})_{0.5 \mathrm{x}} \mathrm{Mo}_{3} \mathrm{O}_{12}(\mathrm{x}=0-1.8)$ compounds were found to be lowered significantly (minimum below 103K) [16]. The phase transition temperature of $\mathrm{Sc}_{2-\mathrm{x}} \mathrm{Fe}_{\mathrm{x}} \mathrm{Mo}_{3} \mathrm{O}_{12}$ materials decreased (minimum 385K) with reducing Fe content according to Wu et al. [14]. The phase transition temperatures of the solid solutions $\mathrm{Cr}_{2 x} \mathrm{Fe}_{2-2 x} \mathrm{Mo}_{3} \mathrm{O}_{12}$ and $\mathrm{Al}_{2 x} \mathrm{Fe}_{2-2 x} \mathrm{Mo}_{3} \mathrm{O}_{12}$ $(0<x<1)$ have been reported to be between those of their two constitutional compounds $\left(\mathrm{A}_{2} \mathrm{Mo}_{3} \mathrm{O}_{12}\right)$ [20], that is, still far above RT. Dual-substitution for $\mathrm{Fe}^{3+}$ and $\mathrm{Mo}^{6+}$ has not yet been reported. What will happen when both $\mathrm{Fe}^{3+}$ and $\mathrm{Mo}^{6+}$ cations are substituted by $\mathrm{Zr}^{4+}$ and $\mathrm{V}^{5+}$ 
cations in $\mathrm{Fe}_{2} \mathrm{Mo}_{3} \mathrm{O}_{12}$ ? In present work, we studied the effects of double-cations substitution in $\mathrm{Fe}_{2} \mathrm{Mo}_{3} \mathrm{O}_{12}$ material on the phase transition temperature and the CTE.

In this paper, we report a near-zero thermal expansion material of $\mathrm{ZrFeMo}_{2} \mathrm{VO}_{12}$. Using $\mathrm{XRD}$, Raman spectra and thermal dilatometry we investigated the structure, phase transition and NTE of the material. Results showed that the prepared material adopts monoclinic structure with space group P2/m (10) at RT. Structure phase transition from monoclinic to orthorhombic phase (space group Pbcn (60)) occurs at 298 312 K, much lower than that of $\mathrm{Fe}_{2} \mathrm{Mo}_{3} \mathrm{O}_{12}(772 \mathrm{~K})$. The CTE was measured by XRD to be $\alpha_{l}=(0.68 \pm 0.17) \times 10^{-6} \mathrm{~K}^{-1}$ and measured by dilatometer to be $\alpha_{l}=$ $(0.36 \pm 0.02) \times 10^{-6} \mathrm{~K}^{-1}$ in the similar range of temperature (about 401 573 $\mathrm{K}$ ). Both the values of CTE are much near zero, and obviously different from the parent material $\mathrm{Fe}_{2} \mathrm{Mo}_{3} \mathrm{O}_{12}(-14.82$ $\times 10^{-6} \mathrm{~K}^{-1}$ ) [21]. The tiny difference between XRD and dilatometry might be caused by the effects of microstructure [22].

\section{Experimental Details}

$\mathrm{ZrFeMo}_{2} \mathrm{VO}_{12}$ sample was synthesized by standard solid-state reaction method. Stoichiometric quantities of commercial chemicals of $\mathrm{ZrO}_{2}(99 \%), \mathrm{Fe}_{2} \mathrm{O}_{3}(99 \%), \mathrm{V}_{2} \mathrm{O}_{5}(99 \%)$ and $\mathrm{MoO}_{3}(99.5 \%)$ were ground together thoroughly with an agate mortar for $2 \mathrm{~h}$. The mixed powder was heated from RT to $973 \mathrm{~K}$ in a furnace at a rate of $5 \mathrm{~K} / \mathrm{min}$, maintained at $973 \mathrm{~K}$ for 4 $\mathrm{h}$, and cooled down slowly in the furnace. The sintered powder was reground, pressed into pellets with length about $3.5 \mathrm{~mm}$ and diameter $13 \mathrm{~mm}$ then sintered again at $973 \mathrm{~K}$ for $2 \mathrm{~h}$. The obtained compact pellets were kept for measurements of linear CTEs.

AXIS SUPRA (Kratos) X-ray photoelectron spectroscopy (XPS) was used to analyze the composition of the synthesized sample. Variable-temperature XRD was performed on a D8 ADVANCE X-ray diffractometer (Germany Bruker) with $\mathrm{Cu} \mathrm{K} \alpha_{1}$ radiation. Diffraction data 
were collected with a step size of $0.01^{\circ}$ in the $2 \theta$ range of $10-80^{\circ}$. Using FullProf software, unit cell dimensions below and above the phase transition temperature were determined with LeBail fit and Rietveld methods, respectively. Orthorhombic $\mathrm{Fe}_{2} \mathrm{Mo}_{3} \mathrm{O}_{12}$ (ICSD code 080449) was used as the starting refined model. A LabRAM HR Evolution Raman spectrometer (France HORIBA Jobin Yvon S.A.A.) with 532/633 nm laser wavelength excitation was used for variabletemperature/RT Raman spectroscopic studies. The linear CTE was measured with a dilatometer (LINSEIS DIL L75/L76) at the heating and cooling rates of 5K/min.

\section{Results}

\subsection{Crystal structure at RT}

Fig. 1 (a) shows the XPS survey spectrum of $\mathrm{ZrFeMo}_{2} \mathrm{VO}_{12}$ at RT. Semi-quantitative XPS analyses reveals that the atomic ratio of the element $\mathrm{Zr}, \mathrm{Fe}, \mathrm{Mo}, \mathrm{V}$ and $\mathrm{O}$ of the prepared sample is about $5.94: 5.75: 12.06: 5.28: 70.97$, which is close to the theoretical calculation result (5.88 : $5.88: 11.76: 5.88: 70.59)$. The element $\mathrm{C}$ comes from the oil pump. The Fe $2 \mathrm{p}$ XPS spectra of $\mathrm{ZrFeMo}_{2} \mathrm{VO}_{12}$ were observed at 710.25 and $724.65 \mathrm{eV}$ for $2 \mathrm{p}_{3 / 2}$ and $2 \mathrm{p}_{1 / 2}$ peaks, respectively, as shown in Fig. 1 (b). The binding energies of $\mathrm{Fe} 2 \mathrm{p}_{3 / 2}$ and $\mathrm{Fe} 2 \mathrm{p}_{1 / 2}$ confirms that the $\mathrm{Fe}$ ions in $\mathrm{ZrFeMo}_{2} \mathrm{VO}_{12}$ are in +3 valance state. From Fig. 1 (c), the binding energies of $\mathrm{V}$ $2 \mathrm{p}_{3 / 2}$ and $\mathrm{V} 2 \mathrm{p}_{1 / 2}$ for the sample are 516.30 and $523.80 \mathrm{eV}$, respectively, suggesting that $\mathrm{V}$ ions are in +5 valance state.

Fig. 1 (d) shows the LeBail fit of the $297 \mathrm{~K}$ XRD pattern of $\mathrm{ZrFeMo}_{2} \mathrm{VO}_{12}$ using the $\mathrm{P} 2 / \mathrm{m}$ (10) space group. The least-squares refinement resulted in $\chi^{2}$ (goodness-of-fit) values $\left(\chi^{2}=\right.$ Rwp/Rexp) about 2.02. The cell parameters were calculated as follows: $a=13.5208 \AA, b=$ $12.9329 \AA, c=12.5732 \AA, \alpha=90.000^{\circ}, \beta=110.927^{\circ}, \gamma=90.000^{\circ}, V=2053.5654 \AA^{3}$. It is indicated that $\mathrm{ZrFeMo}_{2} \mathrm{VO}_{12}$ adopts monoclinic structure with space group $\mathrm{P} 2 / \mathrm{m}$ (10) at $\mathrm{RT}$. 
Besides, no peaks other than those of monoclinic structure were present in the XRD pattern, which ruled out the possibilities of impurity phases within the detection limit of XRD.
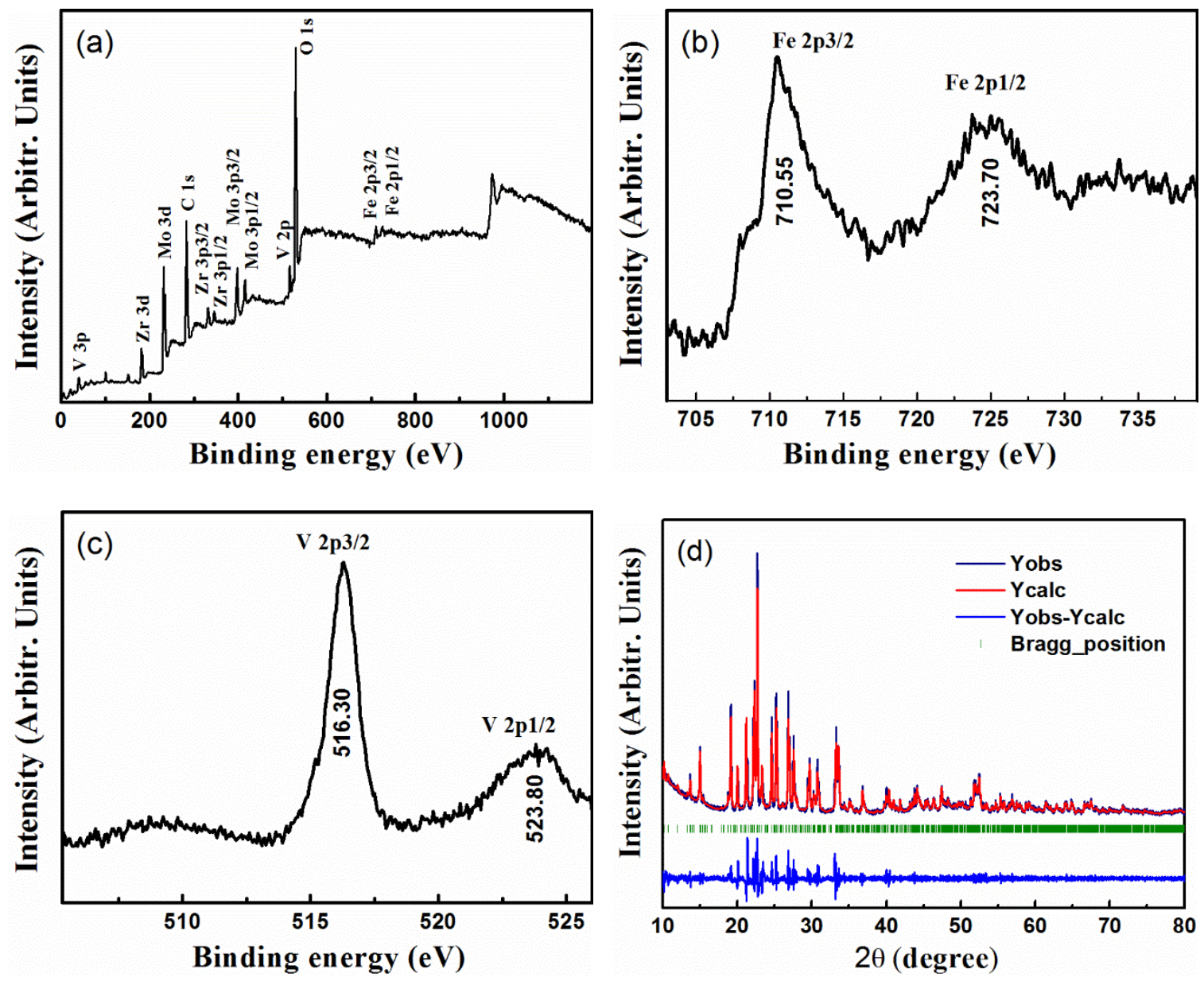

Fig. 1 (a) XPS survey spectrum of $\mathrm{ZrFeMo}_{2} \mathrm{VO}_{12}$ at RT. (b) The XPS spectrum of Fe 2p for the sample. (c) The XPS spectrum of V 2p for the sample. (d) LeBail fit of the $298 \mathrm{~K} \mathrm{XRD} \mathrm{pattern} \mathrm{of} \mathrm{ZrFeMo}_{2} \mathrm{VO}_{12}$ using the $\mathrm{P} 2 / \mathrm{m}$ (10) space group.

\subsection{Phase transition}

Fig. 2a shows the $\mathrm{XRD}$ patterns of $\mathrm{ZrFeMo}_{2} \mathrm{VO}_{12}$ at different temperatures. It can be seen that the apparent difference of the pattern at $297 \mathrm{~K}$ (RT) from the others is the appearance of the peak at $27.0^{\circ}$ (Miller index (113)). It indicates that the RT structure is changed with temperature increasing. Besides, there are no obvious peaks to appear/disappear for the XRD patterns from 
312 to $573 \mathrm{~K}$, suggesting that a non-monoclinic structure maintains with temperature increasing. The non-monoclinic structure is found consistent well with orthorhombic $\mathrm{Fe}_{2} \mathrm{Mo}_{3} \mathrm{O}_{12}$ (space group pben (60)). It is obvious that a phase transition from monoclinic to orthorhombic phase occurs at RT $312 \mathrm{~K}$.
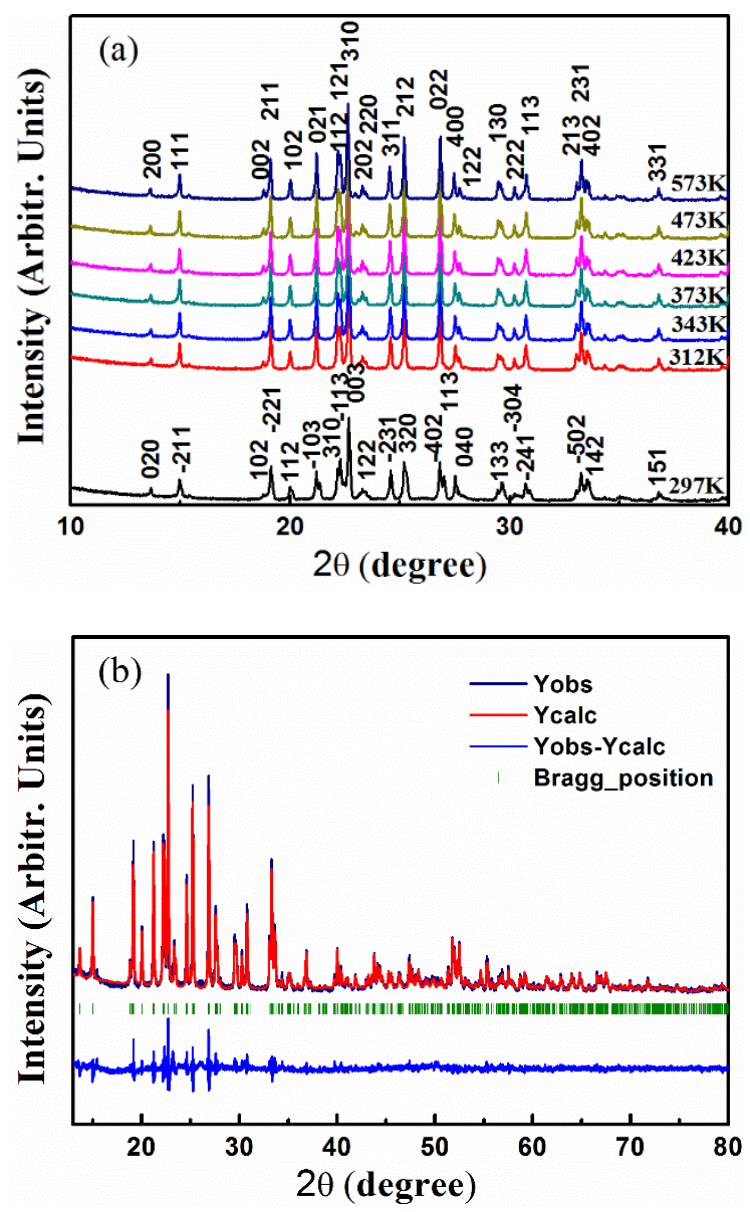

Fig. 2 (a) XRD patterns of $\mathrm{ZrFeMo}_{2} \mathrm{VO}_{12}$ measured at different temperatures. Peaks are indexed for the patterns of $297 \mathrm{~K}$ and $573 \mathrm{~K}$. (b) Results of the Rietveld analysis of the XRD pattern for $\mathrm{ZrFeMo}_{2} \mathrm{VO}_{12}$ at 312 $\mathrm{K}(\mathrm{Rp}=20.4 \%, \mathrm{Rwp}=19.5 \%$, and $\operatorname{Rexp}=11.25 \%)$.

The Rietveld refinement of XRD pattern at $312 \mathrm{~K}$ are given in Fig. 2b. The Rietveld reliability factors are as follows: $\operatorname{Rp}=20.4 \%, \operatorname{Rwp}=19.5 \%, \operatorname{Rexp}=11.25 \%, \chi^{2}=\operatorname{Rwp} / \operatorname{Rexp}=1.73$. The calculated values of cell parameters are: $\mathrm{a}=12.9406 \AA$, $\mathrm{b}=9.3402 \AA, \mathrm{c}=9.4336 \AA \mathrm{A}, \mathrm{V}=$ 
1140.2172 $\AA^{3}$. The refined results further indicated that $\mathrm{ZrFeMo}_{2} \mathrm{VO}_{12}$ adopts orthorhombic structure with space group Pbcn (60) when temperature is at or above $312 \mathrm{~K}$.
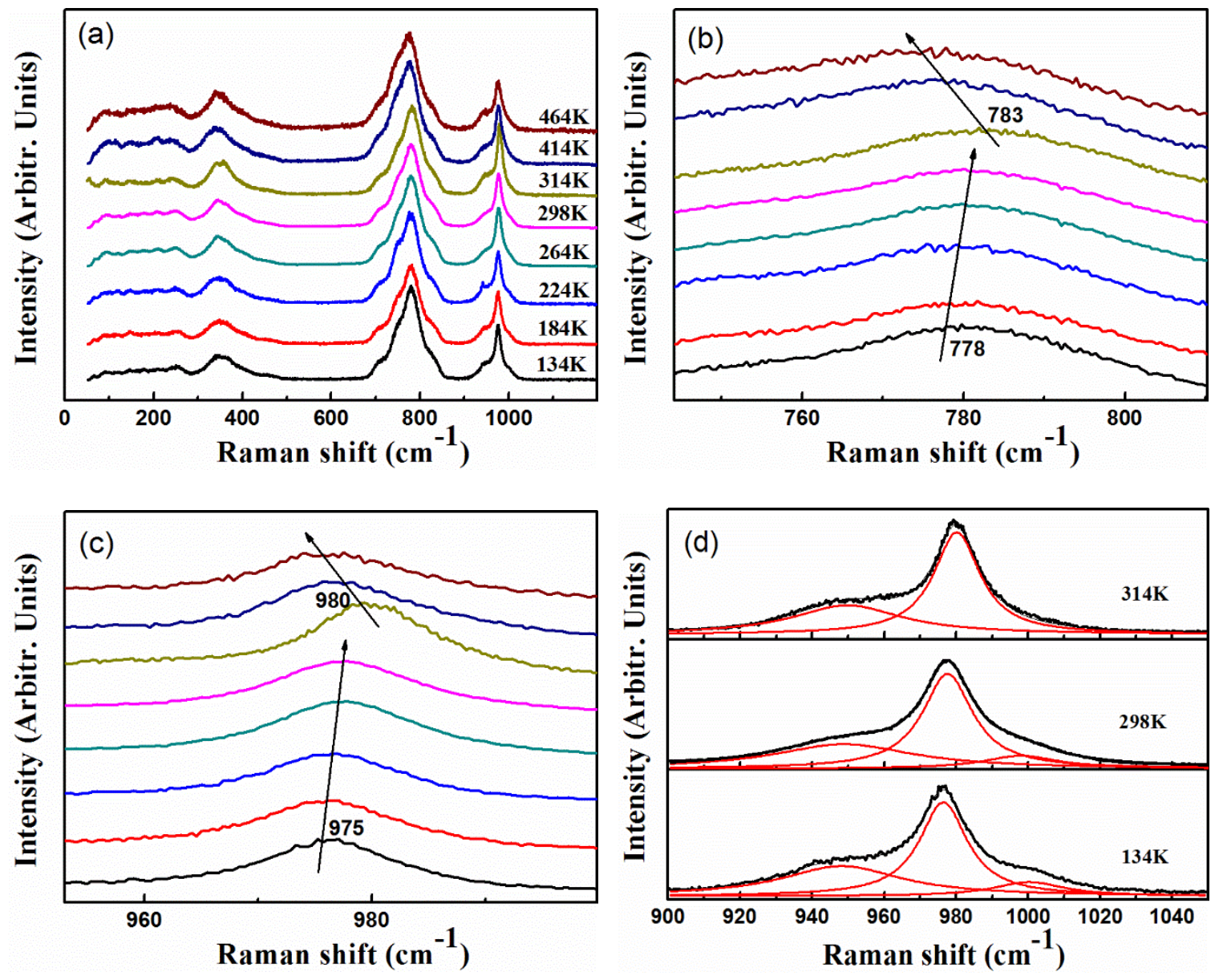

Fig. 3 (a) Raman spectra of $\mathrm{ZrFeMo}_{2} \mathrm{VO}_{12}$ at different temperatures. (b) and (c) are the partial amplification of (a). (d) multi-peak fits of the Raman bands in $900 \sim 1050 \mathrm{~cm}^{-1}$ (The black lines indicate the measured intensities and the red lines represent the fitted Raman curve).

Apart from XRD, variable-temperature Raman spectra were also used to analyze the phase transition. Fig. 3a shows the temperature dependence of the Raman spectra of $\mathrm{ZrFeMo}_{2} \mathrm{VO}_{12}$. Based on the frequencies of $\mathrm{MoO}_{4}$ ions in other molybdates [23] one can assign the internal modes in this material. The Raman modes in the ranges 900-1050,750-950 and 300-400 $\mathrm{cm}^{-1}$ can be identified as the internal symmetric stretching $v_{1}$, asymmetric stretching $v_{3}$ and bending 
vibrations $\left(v_{2}\right.$ and $\left.v_{4}\right)$ of the $\mathrm{MoO}_{4}$ or $\mathrm{VO}_{4}$ tetrahedra and those below $300 \mathrm{~cm}^{-1}$ are translational and librational motions of the $\mathrm{FeO}_{6}$ or $\mathrm{ZrO}_{6}$ polyhedra. As shown by Fig. $3 \mathrm{~b}$ and Fig. 3c, there are obvious changes in the Raman spectra around $783 \mathrm{~cm}^{-1}$ and $980 \mathrm{~cm}^{-1}$. Raman bands around $778 \mathrm{~cm}^{-1}$ and $975 \mathrm{~cm}^{-1}$ successively shift to the higher wavenumber and finally disappear with temperature increasing from 134 to $298 \mathrm{~K}$. However new Raman bands around $783 \mathrm{~cm}^{-1}$ and 980 $\mathrm{cm}^{-1}$ appear at $314 \mathrm{~K}$ and successively shift to the lower wavenumber with temperature increasing. Fig. 3d illustrates the changes of Raman bands by multi-peak fit. The Raman band at about $1000 \mathrm{~cm}^{-1}$ is characteristic for monoclinic structure [15, 16, 23-25] which can be seen for the spectra from $134 \mathrm{~K}$ to $298 \mathrm{~K}$ but disappears at $314 \mathrm{~K}$. It is obvious that there is a phase transition at $298 \sim 314 \mathrm{~K}$, which agrees well with the result of variable-temperature XRD.

\subsection{Thermal expansion property}

Fig. 4A shows dependence of the lattice constants on temperature of orthorhombic $\mathrm{ZrFeMo}_{2} \mathrm{VO}_{12}$ from 312 to $573 \mathrm{~K}$. It can be seen that a-axis expands while b-axis and c-axis contract linearly with temperature increasing. The CTEs from 423 to $573 \mathrm{~K}$ are calculated to be $7.93 \times 10^{-6} \mathrm{~K}^{-1},-2.27 \times 10^{-6} \mathrm{~K}^{-1},-3.62 \times 10^{-6} \mathrm{~K}^{-1}$ for $\mathrm{a}, \mathrm{b}$ and $\mathrm{c}$ axes, respectively. This gives rise to a volume CTE of $2.04 \times 10^{-6} \mathrm{~K}^{-1}$ and a linear CTE of $0.68 \times 10^{-6} \mathrm{~K}^{-1}$ with an uncertainty of $\pm 0.17 \times 10^{-6} \mathrm{~K}^{-1}$. It can be concluded that orthorhombic $\mathrm{ZrFeMo}_{2} \mathrm{VO}_{12}$ exhibits anisotropic thermal expansion properties and near-zero linear CTE.

Fig. 4B shows relative length change of $\mathrm{ZrFeMo}_{2} \mathrm{VO}_{12}$ measured by dilatometry. Due to the apparent phenomenon of thermal hysteresis in the curve, only the heating section is given. An expansion with CTE of $(17.80 \pm 0.35) \times 10^{-6} \mathrm{~K}^{-1}(\mathrm{RT} \sim 350 \mathrm{~K})$ and $(5.22 \pm 0.12) \times 10^{-6} \mathrm{~K}^{-1}$ (351 $400 \mathrm{~K})$ was observed, followed by a near-zero thermal expansion in the temperature region of 401 to $673 \mathrm{~K}$. The appearance of tuning in the thermal expansion curve can be 
explained as monoclinic to orthorhombic structure phase transition accompanied by a large volume change. The phase transition has been demonstrated by variable-temperature XRD and variable-temperature Raman spectra. The linear CTE from 401 to $573 \mathrm{~K}$ is calculated to be about $(0.36 \pm 0.02) \times 10^{-6} \mathrm{~K}^{-1}$, slightly deferent from the XRD measurements. The microstructural effects might be the cause of such difference. The CTE calculated from XRD reveals the intrinsic thermal expansion of unit cell while that measured from delatometry reflects the thermal expansion of bulk material, in which microcracks and poles are inevitable and may affect the measured result. Also the difference between intrinsic (XRD) and extrinsic (dilatometric) thermal expansion can be found in $\mathrm{Al}_{2} \mathrm{~W}_{3} \mathrm{O}_{12}[9,26]$, $\mathrm{In}(\mathrm{HfMg})_{0.5} \mathrm{Mo}_{3} \mathrm{O}_{12}$ [13], etc.
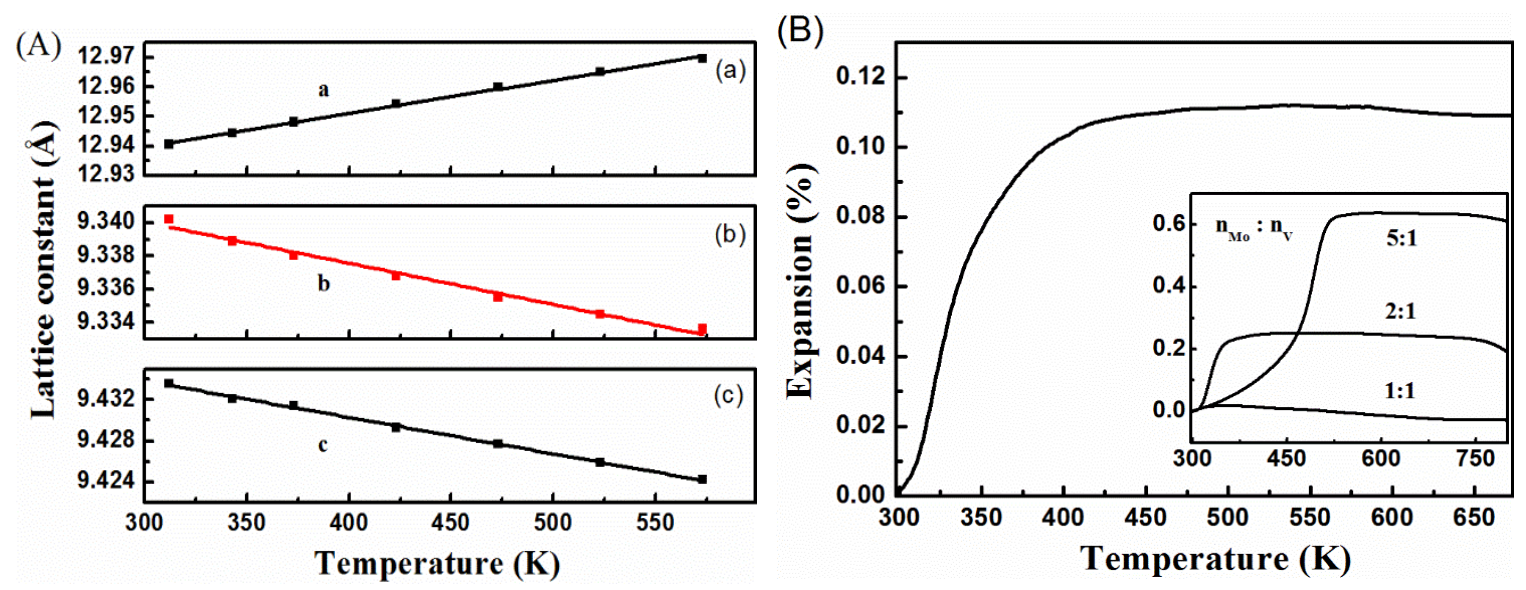

Fig. 4 (A) Temperature dependence of orthorhombic unit cell parameters: obtained from Rietveld refinement of XRD data. (B) Relative length change of $\mathrm{ZrFeMo}_{2} \mathrm{VO}_{12}$ : obtained from dilatometric measurement. The inset diagram shows relative length change of samples with different Mo:V molar ratios.

\subsection{Mechanism of phase transition and near-zero thermal expansion}

The effect of substitution of $\mathrm{Zr}^{4+} / \mathrm{V}^{5+}$ for $\mathrm{Fe}^{3+} / \mathrm{Mo}^{6+}$ on the phase transition temperature is correlated with the electronegativity of cation [17]. Since the electronegativity of $\mathrm{Zr}^{4+}(1.33)$ is smaller than that of $\mathrm{Fe}^{3+}(1.83)$, and the electronegativity of $\mathrm{V}^{5+}(1.53)$ is smaller than that of $\mathrm{Mo}^{6+}(2.16)$, more negative charges are concentrated on the oxide ions, which results in more 
repulsion between the oxide ions for $\mathrm{ZrFeMo}_{2} \mathrm{VO}_{12}$ than for the unsubstituted material. It has been reported that there is an abrupt decrease in volume when the structure transforms from orthorhombic to monoclinic phase (a volume collapse phase transition) [9]. More repulsion means more resistance to a volume collapse during the cooling process, which causes the phase transition to occur at a lower temperature for $\mathrm{ZrFeMo}_{2} \mathrm{VO}_{12}$ than for the unsubstituted material. While in the heating process, more repulsion implies more impetus to restore the volume from collapse, resulting in a lower phase transition temperature. It can be seen from the inset diagram of Fig. 4B that the phase transition temperature decreases with Mo:V molar ratio decreasing, which accords quite well with the theoretical results.

The NTE of orthorhombic $\mathrm{A}_{2} \mathrm{M}_{3} \mathrm{O}_{12}$ was convincingly attributed to the bending of $\mathrm{A}-\mathrm{O}-\mathrm{M}$ linkages on increasing the temperature. And the bending of A-O-M linkages may be caused by the transverse vibrations of the bridging oxygen [27]. As can be seen in Fig. 5a, the orthorhombic $\mathrm{ZrFeMo}_{2} \mathrm{VO}_{12}$ also has $\mathrm{A}-\mathrm{O}-\mathrm{M}$ linkages $(\mathrm{A}=\mathrm{Zr} / \mathrm{Fe}, \mathrm{M}=\mathrm{Mo} / \mathrm{V})$. Considering the double-substitution of $\mathrm{Zr}^{4+} / \mathrm{V}^{5+}$ for $\mathrm{Fe}^{3+} / \mathrm{Mo}^{6+}$, the electronegativity of $\mathrm{A}^{3+}$ cation and the $\mathrm{M}-\mathrm{O}$ bond strength can be used to analyze the NTE of $\mathrm{ZrFeMo}_{2} \mathrm{VO}_{12}$. Since the electronegativity of $\mathrm{Zr}^{4+}(1.33)$ is smaller than that of $\mathrm{Fe}^{3+}(1.83)$, the effective negative charge of oxygen anions increases, resulting in larger oxygen-oxygen repulsion and hence more rigid polyhedra. As shown in Fig. 5b, the stretching Raman band around $980 \mathrm{~cm}^{-1}$ shift to the higher wavenumber with Mo: $\mathrm{V}$ ratio decreasing, which suggests that $\mathrm{M}-\mathrm{O}$ bond becomes stronger or harder with the content of $\mathrm{V}$ increasing. As a result, it is expected that the extent of bending, as mentioned by Tyagi [21], will be less in $\mathrm{Zr}-\mathrm{O}-\mathrm{V}$ (Mo) linkages or $\mathrm{Zr}(\mathrm{Fe})-\mathrm{O}-\mathrm{V}$ linkages than in $\mathrm{Fe}-\mathrm{O}-\mathrm{Mo}$ linkages. Consequently, the substitutions of $\mathrm{Zr}^{4+}$ and $\mathrm{V}^{5+}$ result in near-zero thermal expansion. 

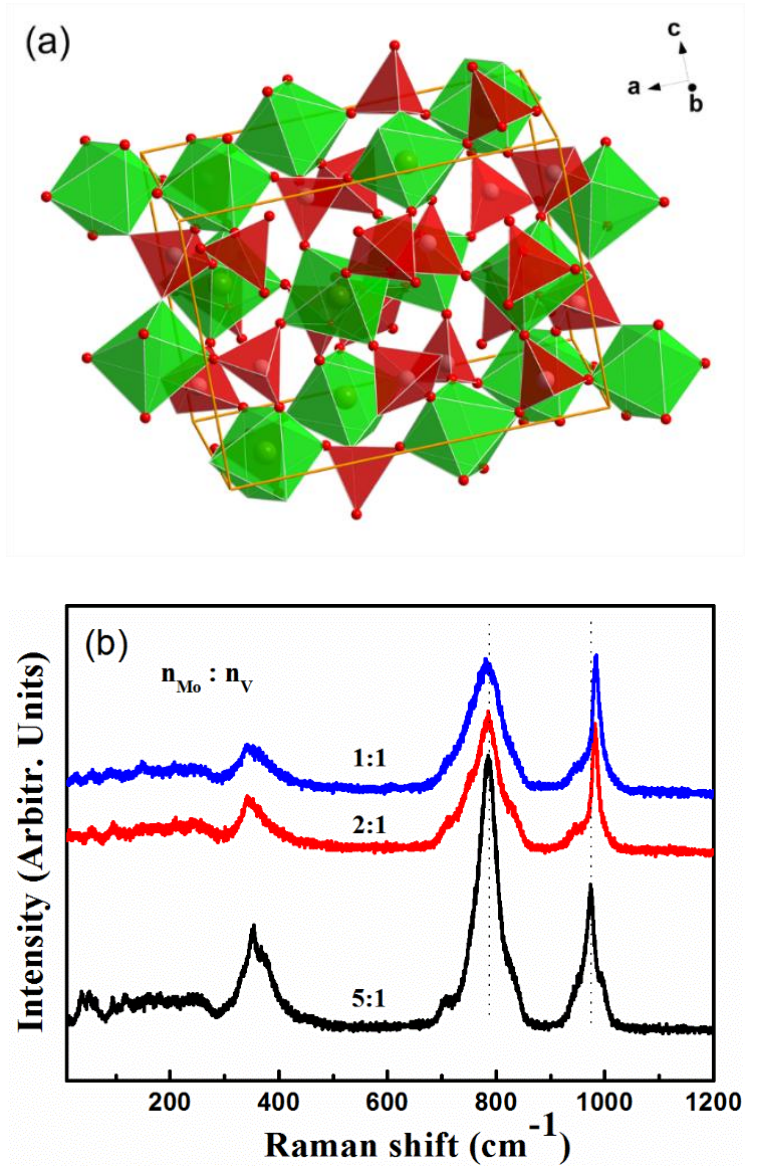

Fig. 5 (a) Rietveld-refined structure of $\mathrm{ZrFeMo}_{2} \mathrm{VO}_{12}$ at $312 \mathrm{~K}$. O atoms are shown in red balls, $\mathrm{Fe}(\mathrm{Zr}) \mathrm{O}_{6}$ octahedron in green, and $\mathrm{Mo}(\mathrm{V}) \mathrm{O}_{4}$ tetrahedron shown in red. (b) RT Raman spectra of samples with different Mo:V molar ratios.

\section{Conclusion}

Using solid method, a new compound of $\mathrm{ZrFeMo}_{2} \mathrm{VO}_{12}$ was synthesized by doublesubstituting of $\mathrm{Zr}^{4+} / \mathrm{V}^{5+}$ for $\mathrm{Fe}^{3+} / \mathrm{Mo}^{6+}$. Structure phase transition from monoclinic to orthorhombic phase occurs at $\mathrm{RT} \sim 312 \mathrm{~K}$, which is much lower than that of $\mathrm{Fe}_{2} \mathrm{Mo}_{3} \mathrm{O}_{12}(772 \mathrm{~K})$. The key factor influencing the phase transition temperature is the electronegativity of cation. Because of the smaller electronegativity of $\mathrm{Zr}^{4+} / \mathrm{V}^{5+}$ than that of $\mathrm{Fe}^{3+} / \mathrm{Mo}^{6+}$, there are more negative charge around the oxide ions in $\mathrm{ZrFeMo} 2 \mathrm{VO}_{12}$ than in $\mathrm{Fe}_{2} \mathrm{Mo}_{3} \mathrm{O}_{12}$, thus the repulsion force between the oxide ions is stronger in $\mathrm{ZrFeMo}_{2} \mathrm{VO}_{12}$ than in $\mathrm{Fe}_{2} \mathrm{Mo}_{3} \mathrm{O}_{12}$ to resist to a 
volume collapse, resulting in a low phase transition temperature in $\mathrm{ZrFeMo}_{2} \mathrm{VO}_{12}$. The $\mathrm{CTE}$ for $\mathrm{ZrFeMo}_{2} \mathrm{VO}_{12}$ was measured to be $(0.36 \pm 0.02) \times 10^{-6} \mathrm{~K}^{-1}$ in the temperature range of $401 \sim 573$

$\mathrm{K}$ by dilatometry while it was calculated to be $(0.68 \pm 0.17) \times 10^{-6} \mathrm{~K}^{-1}(423 \sim 573 \mathrm{~K})$ by XRD. The slightly difference between the two methods was attributed to the effects of microstructure. The thermal expansion properties of crystallographic axes a, b and c are anisotropic. The nearzero thermal expansion was explained as the less extent of bending of $\mathrm{Zr}-\mathrm{O}-\mathrm{V}$ (Mo) linkages or $\mathrm{Zr}(\mathrm{Fe})-\mathrm{O}-\mathrm{V}$ linkages than $\mathrm{Fe}-\mathrm{O}-\mathrm{Mo}$ linkages due to the harder $\mathrm{Zr}-\mathrm{O}$ bond and $\mathrm{V}-\mathrm{O}$ bond.

\section{Acknowledgements}

This work was supported by the National Science Foundation of China (Nos. 10974183, 11574276), Basic and Frontier Technology Research Program of Henan Province (142300410365), the fund for Science \& Technology Innovation Team of Zhengzhou (2011-03), the Key Scientific Research Project of Colleges and Universities of Henan Province (15B140004).

\section{References}

[1] N. Khosrovani, A. Sleight, T. Vogt, Journal of Solid State Chemistry, 132 (1997) 355-360.

[2] B. Yuan, X. Liu, W. Song, Y. Cheng, E. Liang, M. Chao, Physics Letters A, 378 (2014) 3397-3401.

[3] B. Yuan, X. Liu, Y. Mao, J. Wang, J. Guo, Y. Cheng, W. Song, E. Liang, M. Chao, Materials Chemistry and Physics, 170 (2016) 162-167.

[4] T. Mary, J. Evans, T. Vogt, A. Sleight, Science, 272 (1996) 90.

[5] Y. Yamamura, N. Nakajima, T. Tsuji, Physical Review B, 64 (2001) 184109.

[6] J. Jorgensen, Z. Hu, S. Short, A. Sleight, J. Evans, Journal of Applied Physics, 89 (2001). 
[7] C. Lind, A.P. Wilkinson, Z. Hu, S. Short, J.D. Jorgensen, Chemistry of materials, 10 (1998) $2335-2337$.

[8] C. Lind, D.G. VanDerveer, A.P. Wilkinson, J. Chen, M.T. Vaughan, D.J. Weidner, Chemistry of materials, 13 (2001) 487-490.

[9] J. Evans, T. Mary, A. Sleight, Journal of Solid State Chemistry, 133 (1997) 580-583.

[10] X. Liu, J. Wang, C. Fan, R. Shang, F. Cheng, B. Yuan, W. Song, Y. Chen, E. Liang, M. Chao, International Journal of Applied Ceramic Technology, 12 (2015) E28-E33.

[11] E.J. Liang, Recent Patents on Materials Science, 3 (2010) 106-128.

[12] T. Suzuki, A. Omote, Journal of the American Ceramic Society, 89 (2006) 691-693.

[13] K.J. Miller, C.P. Romao, M. Bieringer, Journal of the American Ceramic Society, 96 (2013) $561-566$.

[14] M. Wu, X. Liu, D. Chen, Q. Huang, H. Wu, Y. Liu, Inorganic chemistry, 53 (2014) 92069212.

[15] Z.Y. Li, W.B. Song, E.J. Liang, The Journal of Physical Chemistry C, 115 (2011) 1780617811.

[16] W. Song, B. Yuan, X. Liu, Z. Li, J. Wang, E. Liang, Journal of Materials Research, 29 (2014) 849-855.

[17] A. Sleight, L. Brixner, Journal of Solid State Chemistry, 7 (1973) 172-174.

[18] J.S.O. Evans, T.A. Mary, T. Vogt, Chemistry of materials, 8 (1996) 2809-2823.

[19] P.M. Forster, A. Yokochi, A.W. Sleight, Journal of Solid State Chemistry, 140 (1998) 157158.

[20] M. Ari, P.M. Jardim, B.A. Marinkovic, F. Rizzo, F.F. Ferreira, Journal of Solid State Chemistry, 181 (2008) 1472-1479. 
[21] A.K. Tyagi, S.N. Achary, M.D. Mathews, Journal of alloys and compounds, 339 (2002) 207-210.

[22] L.P. Prisco, C.P. Romao, F. Rizzo, M.A. White, B.A. Marinkovic, Journal of Materials Science, 48 (2013) 2986-2996.

[23] E.J. Liang, H.J. Huo, J.P. Wang, M.G. Chao, The Journal of Physical Chemistry C, 112 (2008) 6577-6581.

[24] V. Sivasubramanian, T.R. Ravindran, R. Nithya, A.K. Arora, Journal of Applied Physics, 96 (2004) 387.

[25] F. Li, X. Liu, W. Song, B. Yuan, Y. Cheng, H. Yuan, F. Cheng, M. Chao, E. liang, Journal of Solid State Chemistry, 218 (2014) 15-22.

[26] T. Mary, A. Sleight, Journal of Materials research, 14 (1999) 912-915.

[27] K.A.P. Alexandra, D.H. Kenton, T.D. Martin, J. Phys.: Condens. Matter, 8 (1996) 1097310982. 